\title{
Priorities in Romania`s energy strategies in the current European and Euroatlantic context
}

\author{
Monica Florentina CALOPEREANU \\ The Bucharest University of Economic Studies, Bucharest, Romania \\ monica.calopereanu@gmail.com \\ Alin-Nicușor CALOPEREANU \\ The Bucharest University of Economic Studies, Bucharest, Romania \\ alin.calopereanu@gmail.com
}

\begin{abstract}
In a world dominated by uncertainties (geopolitical, economic or political), ensuring energy security has become a top priority, both at state level, as well as for supranational alliances (EU, NATO). The paper aims to present, synthetically, the evolution of the adequacy efforts of the Energy Strategies of Romania in the context of contemporary challenges of global security, insisting on two priorities: the internal needs of energy security and the configuration of the alliances that Romania is part of. Romania's energy security concerns were amplified in 2006-2007, but, although several projects were released in public debate, none has been adopted and assumed. Our investigation was based on the current information we have analyzed, compared and synthetized so that we anticipate strategic developments expected over the next twenty years.
\end{abstract}

Keywords: energy strategy, energy security, energy policy, energy market.

\section{Introduction}

Romania's energy sector is undoubtedly one of the most important for the national economy and for each of its citizens. To understand its significance, we consider simultaneously several arguments. Of these, we will give priority to the role of energy in national, regional or international security. Identified information sources relate mainly to official sources, press articles, a series of works about the geopolitical architecture of the extended region of the Black Sea. Most of the news articles are used to represent their respective author's opinion and have been cited in the documentation activity. The views presented in this paper represent our opinion in relation to the subject at the time of its elaboration, future developments may greatly vary in opposite directions.

\section{Energy security}

International security is a fact on which the states, the international organizations and other international actors contribute in different ways and to varying degrees. „National security" is the most commonly used term in defining security. The state is the actor who assumes the role of guarantor of security of the individual, group and sometimes even of regional security. Instead, state security is defined by all political, economic, social, military and environmental conditions needed to ensure the sovereignty, independence and promote national interests (Bărbuț, 2012 p.21).

For some specialists, the energy security means to be insured in terms of resources, control and distribution routes and alternatives. In general, the concept is defined as "secure resources at a reasonable price" (Proninska, 2007, p.216), so it is integrated into a much broader issue than the security triangle of supply - sustainability - competitiveness. 
Terrorism, conflicts or natural disasters explain the attention of policy-makers who face risks of supply, is to ensure security of energy supply. Also, the focus is on the size of overcapacity strategic reserves and surplus infrastructure. Therefore, the prices and the diversity of supply sources are critical components of energy security (Bărbuț, 2012, p.21).

In another vision, the energy security means the production of necessary energy in their own country and as reduced dependence on imports. But the realities of our times showed that large consumers should renounce on the utopia of energy independence and to accept the interdependence energy (Băhnăreanu, 2008, p.27).

All measures which states or groups of states (alliances) take towards ensuring security of energy supply, competitiveness of the energy industry and environmental protection are easily identifiable in the energy policies taken. Such a framework implies the need for a conscious cooperation between different "energy players" (the country, energy companies or consumers) with the scope to overcome difficulties related to these three components. A modern energy policy, clear and transparent, must provide balance, to remove the isssues of unwanted manifestation, such as energy crises and ensure price stability in the sector and the continuity of supplies to consumers (Codoban 2012, p.65).

\section{Elements of the Energy Strategy with strategical impact for the North Atlantic Treaty Organization (NATO)}

Energy security is not just an economic issue, but has become a much deeper one with political and military implications, North Atlantic Treaty Organization (NATO) added energy security theme on Alliance's agenda. As we know, the North Atlantic Treaty Organization (NATO) is an alliance of 28 countries of Europe and North America who joined the North Atlantic Treaty. NATO's essential purpose is to ensure the freedom and security of all its members by political and military means in accordance with the North Atlantic Treaty Nations Charter. The fundamental principle of the Alliance is a common commitment to mutual cooperation between Member States, based on the indivisibility of their security.

The strategic concept of N.A.T.O. provides protection to vital supply routes as one of the critical issues for the security of their organization.

In the statement to the Riga Summit, NATO member states have decided to support the coordinated efforts of the international community to evaluate the risks of energy infrastructures and promote their safety (Paragraph 45 of the Final Declaration of the Summit of the Riga, November 29, 2006). Some officials believe that the Alliance could play an important role in building international political solidarity in case of a deliberate disruption of energy supply (Gallis, 2007, p.7). In this purpose, the Alliance could coordinate their policies in the field, encouraging the exchange of resources in case of short circuit power flows.

If necessary, the Alliance could ensure security of energy infrastructure in the producing countries, and being identified the principles which will guide NATO in the energy security area, establishing that the organization will engage in the following areas: merger and exchange of information, design stability, promoting international and regional cooperation, sustaining the management of consequences and support for protecting critical energy. (Paragraph 48 of the Declaration Summit in Bucharest). 


\section{Energetical Strategy of the states in the geographical area of Romania}

Background Romania's energy strategy is strongly influenced by regional decisions. In the following, we will briefly present the strategic vision of Russia and the European Union.

\section{a) Energy Strategy of Russia}

Russia has considerable energy resources, an energy complex and powerful fuel supplies, which underpins the development of the economy of this country, and is an important instrument of foreign and domestic policy.

Russia`s energy policy objectives (till 2020) are: maximum efficient use of energy, natural fuel and energy sector's potential for economic growth in order to raise the quality of life for citizens; establishing qualitative development paths of the energy, fuel; production and services increased competitiveness in the global market; developing measures and mechanisms of state energy policy, given the expected results for its realization (Bărbuț, 2012, p.126).

In relation to the European Union, there is a concerted activity to increase control over Russian gas sent to Europe, improving control over Georgia, Russian-Libyan relations strengthen, control of Caspian gas, suggesting a EU action surround and sources of gas for it (fleas, 2014, p.39).

\section{b) Energy Strategy of the European Union}

On 8 March 2006 the European Union adopted a new draft energy strategy at Community level, the European Strategy for Sustainable Energy, Competitive and Secure (European Commission - An European Strategy for Sustainable, Competitive and Secure Energy, 8 March 2006).

Between lines of action covered by U.E. to ensure sustainability, competitiveness and energy security we mention: Ensuring the integrity of the internal market, through the adoption of common rules and regulations, but also by building common network or connectivity to existing ones; Ensuring the security of energy flow and consolidation of solidarity between Member States, by reviewing national legislation on oil and gas stocks; Diversification of energy sources; Environmental protection and promotion of energysaving policies; Create a technical strategic plan for energy; Formulation of a common foreign policy for all EU states; Adopt a European Energy Treaty; Adoption of a new energy partnership with Russia; Create a mechanism for reaction to a crisis caused by shortcircuiting of Europe's energy supply.

Following the energy crisis of the years 2006-2007 (gas supply interruptions), EU approved The New Energy Policy of the European Union, with the time horizon 2020 which provides: Reduction of greenhouse gas emissions by $20 \%$, compared with those from 1990; Increasing the share of renewable energy in the total energy mix from less than $7 \%$ in 2006, to $20 \%$ of all energy; Increasing the share of biofuels to at least $10 \%$ of all fuels used; Reduction of primary energy consumption by 20\% (Bărbuț, 2012 p.99).

EU has taken concrete steps towards the gradual building of an internal market of energy, which should guarantee the access to every citizen / community companies to 
energy factors, adopting this way the legislative packages in 1998, 2003 and 2009, aiming mainly gas liberalization of national industries (Codoban 2012, p. 57).

Still unexpressed concrete developments in all their consequences and unsolved from 2014, prompted the European Council (March 2014) to ask the European Commission to develop a comprehensive study on European energy security, which has resulted in the development of a "European Energy Security Strategy" adopted by the Commission on 28 May 2014 and discussed in the Council in June 2014 (Iordan-Constantinescu, 2014, p.36).

Noting that energy security issues were addressed almost exclusively nationwide, the strategy is a "collective approach" through a "functioning internal market and greater cooperation at regional and European level", but also by a "coherent external action "(Iordan-Constantinescu, 2014, p.36).

The strategy is based on eight pillars, each having time horizon 2030: Immediate actions to enhance the capacity of EU to overcome a major disruption of energy imports in the winter of 2014/2015; Strengthen the mechanisms of need / solidarity, including coordination of risk assessments and interventions plans, and infrastructure protection; Moderating energy demand; Achieving a fully integrated and functioning internal market; Increase energy production inside EU; The development of energy technologies; Diversification of external supplies and related infrastructure; Improving the coordination of national policies on energy and communication with one voice on external energy policy (Iordan-Constantinescu, 2014 p.36).

\section{Present and prospects for Romania's energy strategy}

Romania's energy security concerns were amplified in 2006-2007. Romania's Security Strategy adopted by the Supreme Council of National Defense on 17 April 2006 started from the domain`s basic vulnerabilities: dependence on vital resources hardly accessible; weaknesses of strategic infrastructure; inadequate organization of the crisis system; weakness of the domestic capital etc. (National Security Strategy of Romania, 2007)

The strategy emphasizes that the Black Sea region is a major transit area for energy resources and also a space for expression of asymmetric risks and outbreaks of conflict. The region is an important connector located on the corridor which links the Euro-Atlantic community (as a security provider and consumer of energy) to the strategic area Middle East, Caspic Region, and Central Asia (as energy supplier and consumer security).

In terms of energy, the Black Sea region is the main transit area and - in an important way - a major source of energy which is consumed in Europe. Forecasts see an opportunity to substantially increase its share in the coming decades, which gives it a crucial role in the energy security of Europe (Băhnăreanu, 2008, p.241).

On 5 September 2007, the Supreme Council of National Defense approved the Project of Energy Strategy for 2007-2020, project aligned to the main goals and objectives of EU. According to this document, Romania's priorities are: ensuring competitiveness; diversification of energy supply; environmental protection; ensure investments to increase production capacity and development.

If we analyse comparative the Romania's energy strategy priorities and those of the European Union, we can identify easily, some common concerns: maintaining national sovereignty in matters of energy security; increasing security of energy supply; choosing a balanced energy mix (coal, hydro, nuclear, renewables), to provide energy sector 
competitiveness and security of supply; effective management of primary energy resources depleting and maintain an acceptable level of imports of primary energy resources; improving energy efficiency; providing investment to increase capacity for innovation and technological development; fulfill the objectives of environmental protection and reducing carbon emissions. (Bărbuț, 2012, 145-146).

The overall objective of the strategy is reaching the energy needs at the lowest possible price, suitable for a modern market economy and a decent living standard in terms of quality, food safety, while respecting the principles of sustainable development.

Landmarks actionable of the strategy, in 2020, are: Maintaining a balance between imports of primary energy resources and rational and efficient use of the national reserves trade and economic base; Diversification of sources of supply of raw materials and develop their transport routes; long-term contracts to import natural gas, respecting competition rules; Increased investment in coal mining and uranium ore, in accordance with EU regulations; Increased investment in the exploitation of natural gas reserves, the development, rehabilitation and dispatching natural gas pipelines in increasing natural gas storage capacity; Restructuring and renewal of electricity generation capacity by rehabilitating existing viable units, closure of unviable units and construction of new production facilities; Further development, modernization and upgrading of transmission and distribution networks; Continued development programs, of transmission and distribution of thermal energy, development, modernization and upgrading of electricity production units and heat; Address, jointly with Member States, the issues relating to the protection of critical infrastructure in the energy system in the fight against terrorism (Romanian Energy Strategy 2007-2020, July 2007).

\section{Priority development projects provided by the Romanian Energy Strategy until 2035}

Between 5 December 2014 and 10 January 2015, was launched for the public debate the National Energy Strategy for the period 2015-2035, the deadline for completion of the review of the national energy strategy is May 2015 (http://www.agerpres.ro/economie/2014/12/05/strategia-energetica-nationala).

This document supposed to be the foundation on which future scenarios will be formulated for the development of Romanian energy system and energy policy proposals, to be adopted in the next 20 years. The document, subject to public debate, was developed by the Department of Energy, with the participation and consultation of several experts from academia, business and society. The necessary investments in the area are estimated to be 100 billion euros by 2035 (Energy Strategy, the current state analysis).

Investment objectives or strategic deemed necessary for Romania's energy security are: Development of Units 3 and 4 of CNE Cernavoda, currently under negotiations for the participation of China General Nuclear Power Corporation; developing hydroelectric pumped storage Tarnița - Lăpuştești (2020 would be rehabilitated and upgraded hydro 2,400 MW, almost half of the total capacity of the state company Hidroelectrica. Other hydropower capacity development plans by 2025 include construction of four groups with a total installed capacity of $32.9 \mathrm{MW}$ at the intersection of the Danube with the Olt river); developing smart metering infrastructure (deployment of smart metering of electricity) and 
smart grid network (INTELIGENTA- a symbiosis between the components of an electrical network in the traditional sense of the word and the elements of information technology and communications that come complete functionality that networks ); Developing or expanding interconnection capacity and facilitate export / import for exploiting the advantage of higher electricity prices in other markets, and to help increase market liquidity and export natural gas; exploitation of natural gas deposits in the Black Sea and ensuring the security of natural gas supply, export physical capacity expansion, construction of pipeline transport capacity coupled with expected production and increasing investment in extractive capacity of storage facilities; investments to comply with EU environmental requirements; modernization of coal plants (Energy Strategy, the current state analysis), liberalization of energy markets; the need to respect EU policies and objectives in the energy sector, including those aimed at further investment in production capacity from renewable electricity generated

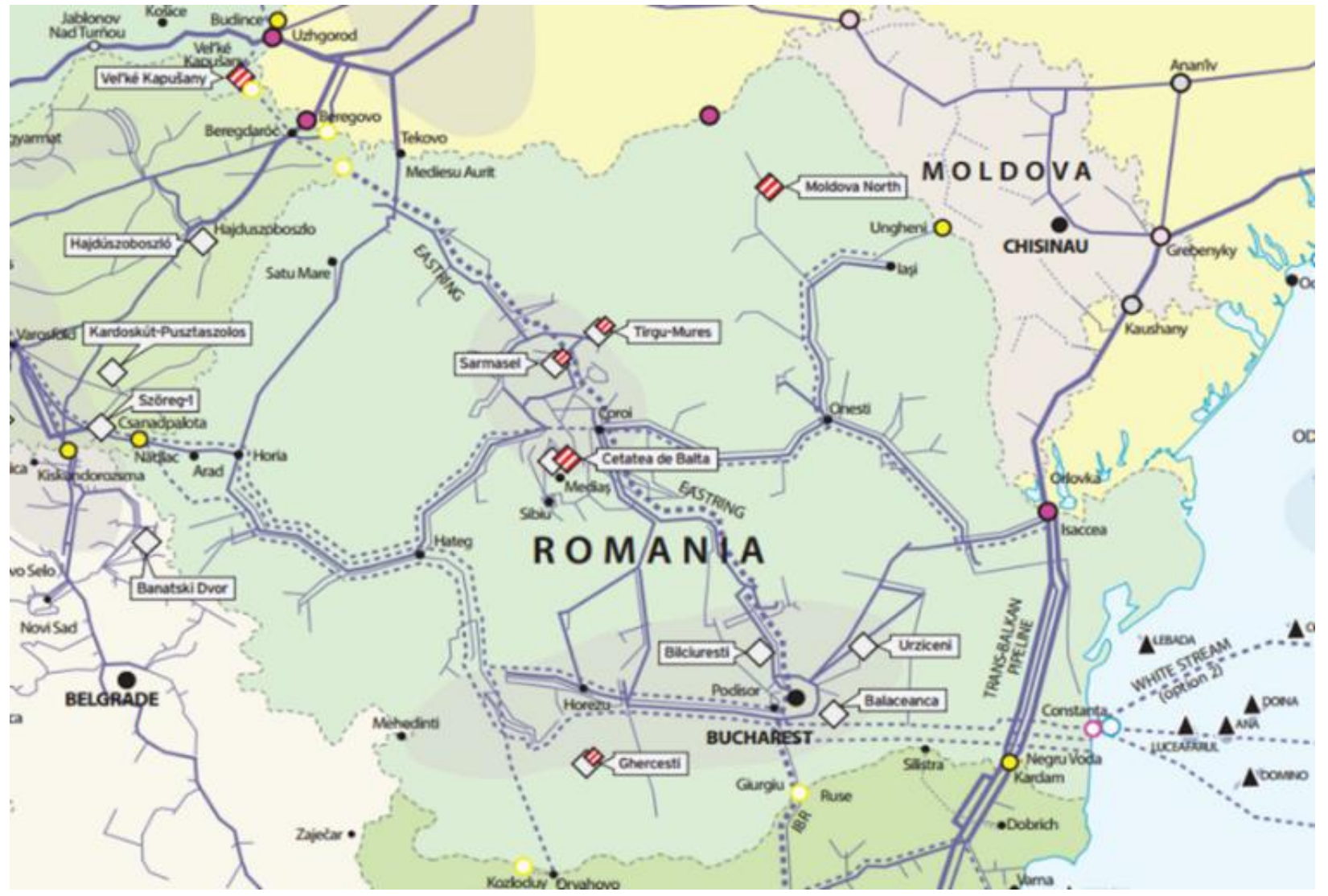

Figure 1. Romanian and regional gas pipeline system (including future projects)

Source: Own processing.

In terms of investments in the energy sector is expected that the following factors will have a significant impact on medium and long term strategic objectives on energy security, such as: Efficient exploitation of primary energy resources; Upgrading of existing electricity production capacity and development of new capabilities; Interconnection capacity development; Developing and improving infrastructure performance in gas and 
electricity; Discovery of new oil and gas resources (Energy Strategy, the current state analysis).

\section{Romanian development strategy for the next 20 years from the Romanian Academy point of view}

In 2015 it was published the first volume of Romania's development strategy for the next 20 years under Ionel Valentin Vlad's coordination, the president of the Romanian Academy. Within it we can find an entire chapter regarding Energy Strategy and Energy Efficiency, written by prof. Filip Cârlea, Ph.D.

The document emphasizes the energy efficiency as the backbone of the entire development of the energetic system. In the near future, the Romanian hydrocarbon reserves exploitation and some sort of vulnerability derived from the Russian takeover of the Crimean territory have been identified as the major elements which can affect Romanian energy security.

According to the Romania Academy's point of view amongst the objectives of the energy projects which our country should develop, there are: The valorization of the onshore potential of oil, hydrocarbon and natural gases; The development of the national system of gas and oil transportation infrastructure;Identifying the role of the hydrocarbon sector in the national energy system;The development of the hydro capabilities;The strategic projection of the nuclear sector, including the perspective of supplying with fuel from autochthon sources; The development of the energy efficiency policy; The encouragement of the electric energy consumption and defining the role of the renewable resources; The Romanian technical profile, based on intelligent networks.(Ionel Valentin Vlad, 2015)

\section{Romanian Energy Strategy 2016-2030 with a 2050 perspective}

On November 15, 2016, it has been launched a public debate regarding The Romanian Energy Strategy 2016-2030 with a 2050 perspective. The new strategy has five fundamental objectives: Energetic security; The establishment of competitive energy markets as basis for a new competitive economy; Clean energy sustaining the energetic system; Updating the energetic governance system; The protection of the assailable consumer and reducing the energetic poverty.

For a better understanding of the strategic options, there has been made a complex and detailed study of macroeconomic remodeling with numeric stimulation and comparing almost 50 scenarios, sub- scenarios and sensitivities. The modeling was made by the international association "Ernst \& Young" - E3Modelling (Greece), which used the models PRIMES/GEM-E3, also used by the European Commission. 


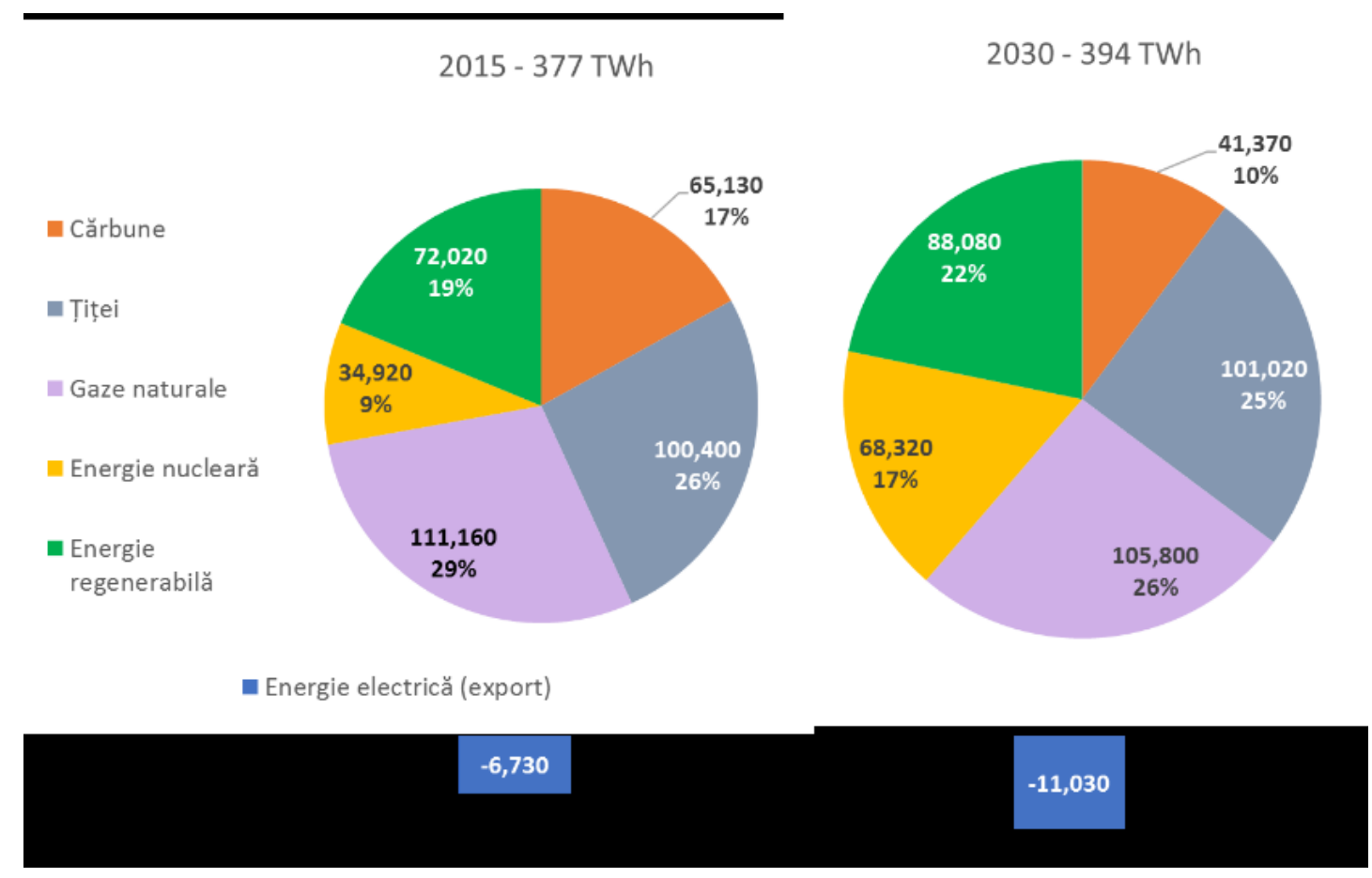

Figure 2. The structure of primary energy production in 2015 and 2030 Source: E\&Y.

According to the data from the Romanian Energy Strategy 2016-2030 project, the natural gases could become the main combustible in the year 2030 for the internal production of energy, followed by the nuclear energy. The necessary investments in the Romanian energetic sector raise up to 1.5-2 billion euros per year, according to the same preliminary data.

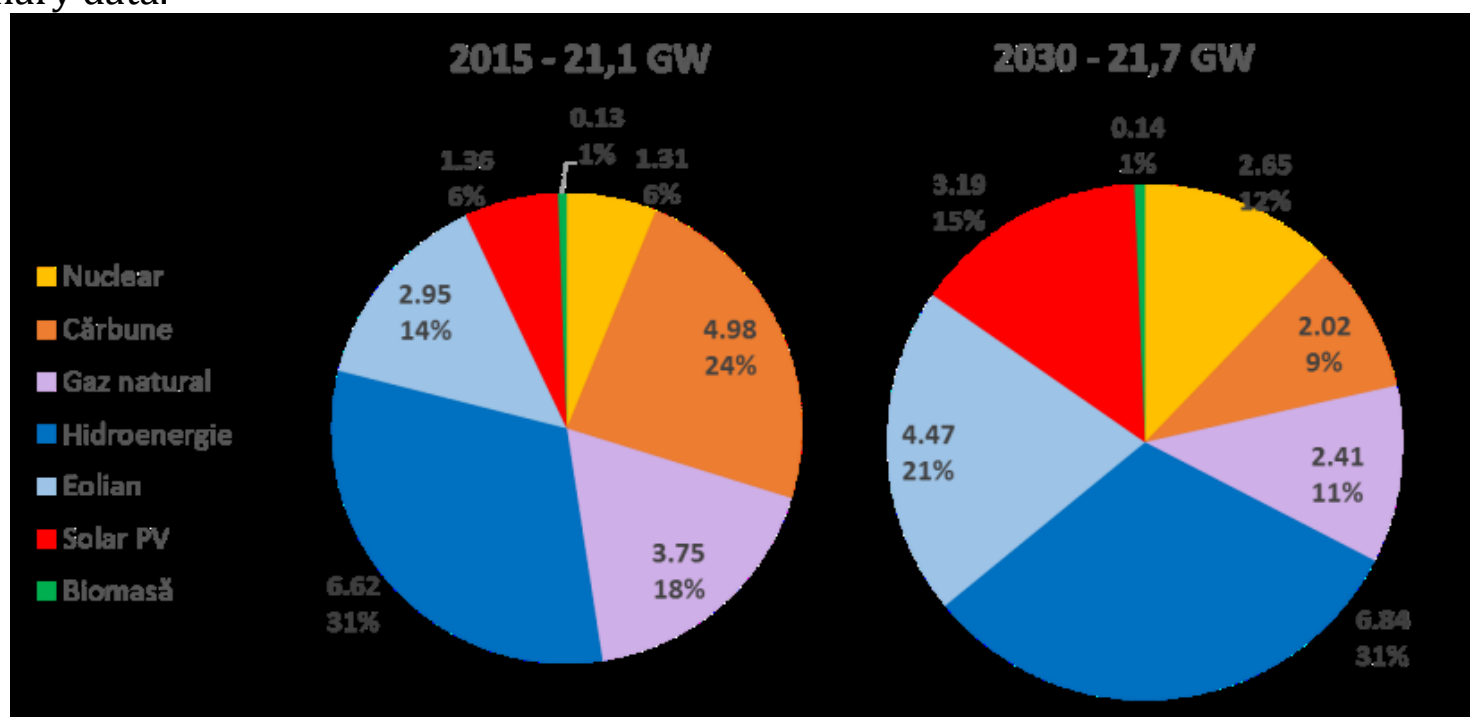

Figure 3. The structure of brute electic power

Source: E\&Y.

However, the raising of the gas usage in energy could be mean a raising in the Russian addiction. On the other hand, the international pattern shows a graduate reduction of the coal production capabilities due to the high costs and pollution. 


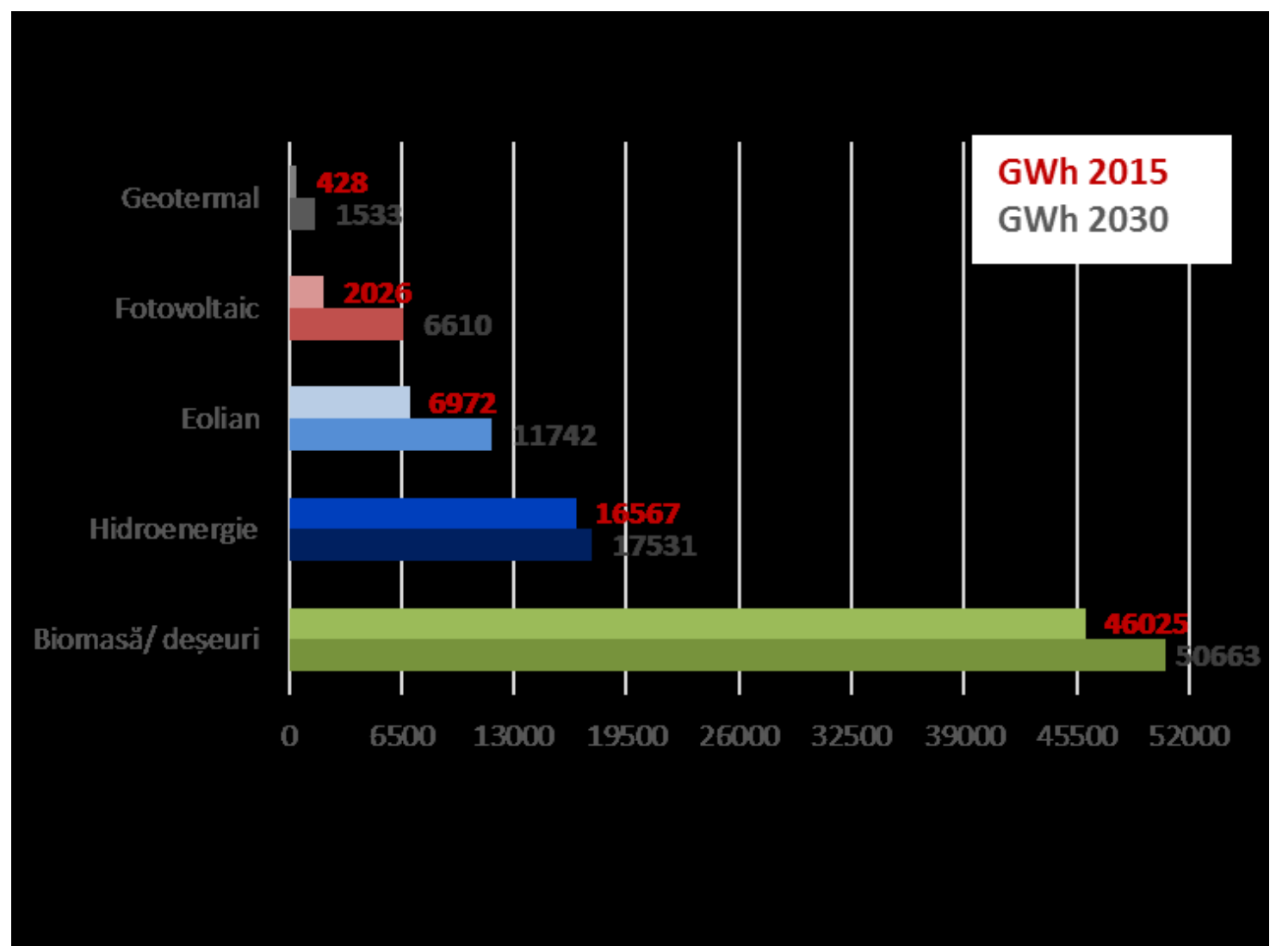

Figure 4. The structure of green energy in Romania 2015 / 2030

Source: E\&Y.

In 2030, the installed predicted energy power will decrease from 18.000 MW up to 16.000 MW and in the same tine in Romania there will be functional 4 nuclear reactors, two more than in the present time. (if Nuclearelectrica and CGN China partnership will become effective). At that time there will be at least one big hydroelectric power plant - Islaz and the green resources production will cover 20\% from the entire energetic production mixture.

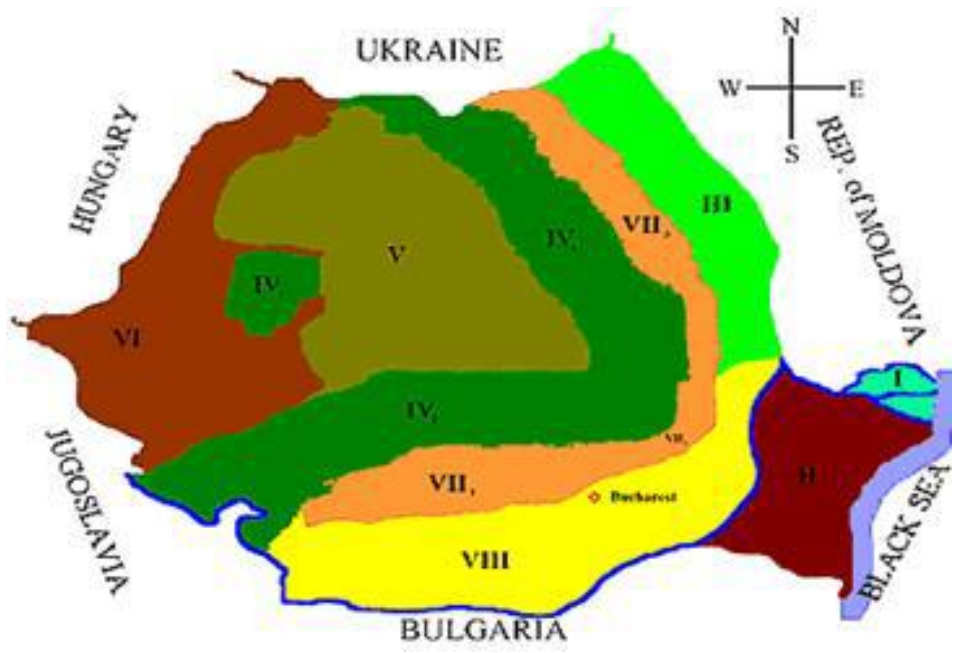

Figure 5. The map of renewable energies capacities in Romania 
Legend:

Source: E\&Y.

I. Danube Delta (solar energy);

II. Dobrogea (wind and solar energy);

III. Moldavia (microhidro, wind energy and biomass);

IV. Carpathian Mountains (biomass, microhidro);

V. Transilvanian Plateau (microhidro);

VI. Western Plain (geothermal energy);

VII. Subcarparthians ( biomass, microhidro);

VIII. Southern Plain (biomass, solar and geothermal energy).

\section{Conclusion}

In our opinion, the main problem in shaping a valid project regarding Romanian Energetic Strategy is represented by the instability of the legislation and the lack of a unitary vision in the field.

As presented, in less than 3 years there have been released in the public media at least three national energy strategies (without taking into consideration the projects released at the EU level) which didn't have a common development vision. Moreover, these strategies have not been adopted as official documents by the Romanian state.

As the main block that discouraged the development/modernization of the national energetic system we can identify the instability of the energetic and financial legislation, the taxes on special construction introduced by the government in 2014 (presently suspended), the lack of public policies and the numerous postponements of the new investments, the lack of institution/structures specialized in the risk management of the energy security domain.

From our point of view the projects of the energetic strategy for 2030-2035 deal superficially with the non-polluting, renewable energies and they are not made for developing an action plan based on the absolutely enormous Romanian potential on the biomass level; the Romanian Energy Strategy for 2016-2030 considers biomass as plain fire wood.

Moreover, the Romanian Energy Strategy for 2016-2030 anticipates the renouncement to the facilities granted to the green energy producers which will lead to a drastic investment limitation in this branch and consequently to assume new technologies which are friendly with the environment.

The development of major projects in the capacities of production of electric energy from cogeneration, biomass, anaerobic digestion / biogas, together with the primary resources that still exist on out national territory, could lead our country towards the goal of becoming a recognized energy exporter.

Furthermore, adopting special programs of developing the production capabilities based on some private-public partnership as well as granting inputs for construction new medium and small capacities as opposed to the big investments (which only the state actors or the transnational companies can achieved) could lead to a continuous development in the energetic field according to the newest technologies. Another opportune approach is the pursuit of developing the existing policies of efficient energy and of limiting the energetic system losses together with the growth of research and innovation in the field. 
We appraise that the geostrategic instability and the emergency of the events on the long term as well as on the short one will impose the implementation of some concrete action measures at the strategic level, including the continuous adaption of the security strategies to the energetic system, at the national as well as EU level.

\section{Bibliography}

Bărbuț D.M. (2012). Energy strategy in the context of modern security, ED. Top Form, Bucharest.

Proninska, K. (2007). Energy and security: regional and global dimensions, Yearbook 2007 Armaments, Disarmament and International Security, Oxford University Press, 2007, p.215-240.

Băhnăreanu, C. (2008). Energy resources, crises, conflicts, Ed. Military, Bucharest.

Codoban, A. (2012). Russia and Europe in the race for power. Natural gas: between economics and geopolitics, ed. Ars Docendi, Bucharest.

Gallis, P. (2007) NATO and Energy Security, CRS Report for Congress.

Purica, I. (2014). NATO and energy security of the EU, in Vasile Simileanu, Flavius CabaMaria (eds.) - New dimensions of energy strategies in the Middle East and North Africa, Ed. Top-Form, Bucharest.

Iordan-Constantinescu, N. (2014). The need of a new energy policy in the European Union, in Vasile Simileanu, Flavius Caba-Maria (eds.) - New dimensions of energy strategies in the Middle East and North Africa, Ed. Top-Form, Bucharest.

Vlad, I.V. (2015). Strategia de dezvoltare a României în următorii 20 de ani, vol. I, Ed. Academiei Române.

Fierro, J. 2016. Strategia Energetică a României pentru 2016-2030 a fost finalizată, BURSA.

Final Declaration of the Summit in Riga, 29 November 2006, available at www.nato.int/docu/pr/2006.htm.

Declaration of the Bucharest Summit, available at www.summitbucharest.ro.

European Commission - European Year Strategy for Sustainable, Competitive and Secure Energy, 8 March 2006 - www.ec.europa.eu/energy/green-paper-energy.

Romanian President. (2007). The National Security Strategy of Romania, available at www.presidency.ro.

Romanian Government. (2007). Draft Energy Strategy of Romania in 2007-2020, available at www.minind.ro.

Ministry of Economy. (2007). The Romanian Energy Strategy 2007-2020, available at www.minind.ro.

Ministry of Economy. (na). Updated energy strategy for Romania, available at http://www.minind.ro/energie/STRATEGIA_energetica_actualizata.pdf. 